\title{
A TYPOLOGICAL OVERVIEW OF EEGIMAA (JÓOLA BANJAL) ${ }^{1}$
}

\author{
Serge Sagna \\ University of York, United Kingdom
}

\begin{abstract}
This paper presents some of the most prominent properties of Eegimaa, a Jóola/Diola ${ }^{2}$ language spoken in the Basse-Casamance (Southern Senegal). The phonological features examined include [ATR] vowel harmony, backness harmony, lenition, and Eegimaa's typologically unusual geminate consonants. Most of the paper, however, focuses on Eegimaa morphology. My analysis of the noun class system separates morphological classes from agreement classes (genders), and presents the most important principles of semantic categorization, including shape encoding. I also show that Eegimaa classifies nouns and verbs by the same overt linguistic means, namely, noun class prefixes. I argue that this overt classification of nouns and verbs reflects parallel semantic categorization of entities and events. Other prominent typological features include associative plural marking and nominal TAM marking with the inactualis suffix, which also expresses alienability contrasts.
\end{abstract}

Keywords: Atlantic; Jóola; noun class semantics; non-finite verb classification; alienability; Nominal TAM; geminates, vowel harmony

\section{Introduction}

Gújjolaay Eegimaa (Eegimaa for short) is a member of the Jóola cluster of languages spoken in southern Senegal. I provide an overview of selected grammatical features of Eegimaa, with a focus on morphology. Some of the grammatical phenomena are discussed within the context of related Jóola languages but also within a broader typological context. Many of the phenomena appear in available descriptions of Eegimaa (Bassène 2007; Tendeng 2007; Sagna 2008; Bassene 2012), but most of the phenomena I examine here feature a new analysis.

1 The support of the ESRC (grants ES/K0011922/1 and ES/K001922/1) and ELDP (grant IPF 0141) is gratefully acknowledged. I would like to thank Erich Round, Yuni Kim, Matthew Baerman, Stuart Davis and Abbie Hantgan-Sonko for comments on aspects of earlier versions of this paper. I also wish to thank Martin Haspelmath for answering my questions on alienability contrasts. Finally, I would like to thank Tucker Childs for detailed comments that helped improve the content of this paper, and Marilyn Vihman and Mary Raymond for proofreading it. I remain solely responsible for the claims made here.

2 The orthographic system used in the rest of this paper is based on Sagna (2011b), which is adapted from the Senegalese Code for the transcription of national languages. An acute accent is placed on the first vowel of a word to indicate that its vowels belong to the [+ATR] set. When the vowels are [-ATR] no accent is added. Since the word Jóola has [+ATR] vowels in all known Jóola language varieties, it is spelt with an acute accent on its first vowel. Note that in some works, Jóola is spelt <Joola>, disregarding the [+ATR] distinction. There are also publications where it is spelt $\langle$ Diola $>$. This spelling, which is based on French, will not be used in this paper. The vowel [o:] in most Jóla languages is long, hence the doubling of the vowel in <Jóola $>$. Although Eegimaa itself lacks phonological long vowels, I will continue to use the spelling <Jóola> to talk about these languages as a group because Eegimaa is unusual in having geminates where the other Jóola languages have long vowels. . Note that the doubling of vowels in the Eegimaa orthography indicates phonetic length. Phonologically contiguous vowels always belong to different syllables. Other important orthographical notations include the following: $\langle\mathrm{j}\rangle=[\mathrm{f}],\langle\tilde{\mathrm{n}}\rangle=[\mathrm{n}],\langle\mathrm{c}\rangle=[\mathrm{J}]$. Gemination is shown by consonant doubling . 
I begin with some comments on classification and continue with an overview of the segmental phonology in Section 3, where I discuss processes such as vowel harmony and lenition. The morphological structure is investigated in Section 4. It includes an overview of the noun class system and the overt classification of non-finite verbs, a typologically unusual phenomenon (McGregor 2002), which in Eegimaa is characterized by the morphosyntactic classification and the semantic categorization of non-finite verbs using noun class markers. A survey of the TAM system is also provided and incudes an analysis of the inactualis TAM suffix -en, which functions as a Nominal TAM marker, expressing both past possession and alienability contrasts with nouns (see Nordlinger \& Sadler 2004 for a cross-linguistic survey). A brief discussion of some basic aspects of Eegimaa syntax is provided in Section 5. The discussion is summarized in Section 6.

\section{Classification and genetic affiliation}

2.1. Classification and location. Eegimaa is a member of the cluster of Jóola languages belonging to Sapir's (1971) BAK ${ }^{3}$ group of the Atlantic family of the Niger-Congo phylum ((Pozdniakov \& Segerer, In press). Jóola languages are native to the Gambia, the Lower or (Basse) Casamance area of southern Senegal, and the north of Guinea Bissau. The term "Eegimaa", ${ }^{4}$ as Sambou (1989) points out, is used by speakers to distinguish their language from other related Jóola languages. Other popular names for this language include "Endungo", a name used by the neighbouring speakers of the Bayot language. But the most popular kinds of names for this language are those derived from village names and used both by speakers and outsiders. "Banjal" ('the language of Banjal'), which is the most popular of these names, is generally used by speakers from the Jóola Fógny and Búluf areas. Increasingly, native speakers of Eegimaa use its Eegimaa equivalent, the term "Gubanjalay" 5 (Banjal), to refer to their language. "Kusiilay" ('the language of Essil') is another name used for Eegimaa by speakers of Kujireray from the neighbouring village of Brin. Eegimaa is known as "Gúlaay" ('the language of Sállagi') by speakers from the area of Sállagi. This name is the one used by speakers of Jóola Kaasa (pronounced as [kúlaakiay]. In the linguistic literature the names used for Eegimaa are "Gújjolaay" and "Jóola Eegimaa" (Sambou 1989; Sagna 2008; Bassene 2012); Jóola Banjal (Sapir 1971; Bassène 2007) and Gusiilay (Tendeng 2007). Notice that Tendeng (2007) uses "Gusiilaay" ('the language of Essil') to refer to Eegimaa because many speakers argue that Gusiilay is the original name for the language, which reflects the fact that Essil was founded the first of all Mof-Ávvi villages. But this name is potentially confusing, since Gusiilaay is also used for the Jóola variety spoken in Thionk-Essil, a village located on the north bank of the river Casamance whose founders migrated from Essil.

Eegimaa is spoken in a polity (Kopytoff 1987) of ten villages, commonly called the kingdom of Mof-Ávvi ('the king's land'), traditionally governed by a sacred king. The territory is located on the south bank of the Casamance River and extends from the west of Ziguinchor, the capital city of the southern region of Senegal, to the southwest of the city. Lects closely related to Eegimaa are spoken on the north bank of the Casamance River in villages including Affiniam, Boutam, Djilapaor, and

\footnotetext{
${ }^{3}$ The name $B A K$ is given to a group of languages of the Atlantic family for which the plural personal marker has the form $B(V) K$ (Sapir 1971), where (V) stands for different vowels.

${ }^{4}$ Eegimaa means 'here is what I am telling you'. Since the term is not found in other Jóola languages in this form, it is used by Eegimaa speakers to distinguish their language from other Jóola languages.

${ }^{5}$ The prefix $g u$ - is the noun class prefix used for language names in Eegimaa. Its equivalent in most other Jóola languages is $\mathrm{ku}$.
} 
Thionk-Essil. There are also settlements of Eegimaa speakers in multilingual villages such as Djifanghor and Bourofaye located East of the City of Ziguinchor. But today, the largest of Eegimaa diaspora communities are found in Ziguinchor and in Dakar, the capital city of Senegal.

\section{Phonology}

3.1. Vowels and vowel harmony. One of the most notable features of the Eegimaa phonological system in contrast to other Jóola languages is that there are no phonologically long vowels, as in Jóola Fogny (Sapir 1965) and Jóola Kaasa Esuulaalu? (Sambou 1979). Instead, Eegimaa has geminate consonants preceding short vowels that are long in other Jóola languages. This typologically unusual feature (Stuart Davis and Eric Round p.c.) is illustrated in example (1), ${ }^{6}$ showing that Eegimaa length is on consonants rather than on the vowels that bear the length feature in closely related languages.

$\begin{array}{lll}\text { Eegimaa } & \text { fI-ttIx } & \text { 'war' } \\ \text { Esuulaalu? } & \text { x -tIIk } & \text { 'war' } \\ \text { Fogny } & \text { fo-tIIk } & \text { 'fight/war' }\end{array}$

Eegimaa geminates also occur in places where voiceless NC consonant clusters are found in other Jóola languages, because NC consonant clusters of this type are not permitted in the language. Example (2) illustrates these correspondences between Fogny and Eegimaa.

\begin{tabular}{|c|c|c|c|}
\hline $\begin{array}{l}\text { Eegimaa } \\
\text { appa }\end{array}$ & 'dad' & $\begin{array}{l}\text { Fogny } \\
\text { ampa }\end{array}$ & 'dad' \\
\hline gəsotten & 'to treat' & kasonten & 'to treat' \\
\hline
\end{tabular}

3.1.1. [ATR] vowel harmony. Eegimaa has a ten-vowel system, with two sets that differ in terms of what is commonly described as [+/-] Advanced Tongue Root, as shown in Table 1.

Table 1. The two [ATR] vowel sets in Eegimaa

\begin{tabular}{|c|c|c|c|}
\hline \multicolumn{2}{|c|}{ [-ATR] } & \multicolumn{2}{|c|}{ [+ATR] } \\
\hline I & $\boldsymbol{U}$ & $\mathbf{i}$ & $\mathbf{u}$ \\
\hline$\varepsilon$ & $\mathbf{0}$ & e & 0 \\
\hline \multicolumn{2}{|c|}{$\mathbf{a}$} & $\partial$ & \\
\hline
\end{tabular}

The type of vowel harmony found in Eegimaa is, in Clement's (2000: 135) terms, a dominant harmony system. Vowels in a word tend to be either [-ATR] or [+ATR], as exemplified in Table 2.

\footnotetext{
${ }^{6}$ Phonetic notation is used in this section only. I use Eegimaa orthography in the rest of the paper.

7 There are exceptions to this generalization: for example, the vowel [a] in words like [oxula], where it does not harmonize, functions as an opaque vowel by blocking vowel harmony.
} 
Table 2. [ATR] harmonic sets in Eegimaa

\begin{tabular}{ll|ll}
\hline [-ATR] & & [+ATR] & \\
\hline fill & 'breast' & fiil & 'palm tree inflorescence' \\
gacl & 'noise' & gəel & 'mind a child' \\
ambala & 'fisherman' & gəbbəßə & 'chili' \\
joffor & 'kind of fish' & nondon & 'nape' \\
botorm & 'mouth' & jug:ur & 'dwarf' \\
\hline
\end{tabular}

In Eegimaa and other Jóola languages (Sapir 1965; Sambou 1979, 1989; Sambou and Lopis 1981; Bassène 2007; Tendeng 2007; Sagna 2008; Bassene 2012), dominant vowels in vowel harmony are those of the [+ATR] set, which occur only in roots and in certain suffixes. In general, vowels of the [-ATR] change in quality when there is a dominant vowel in the root or suffix. This is exemplified in (3), where [+ATR] forms are highlighted in boldface.

\begin{tabular}{|c|c|c|}
\hline Input & Output & Gloss \\
\hline$\varepsilon$-фur- $\varepsilon n$ & e- $\phi$ ur-en & 'remove' \\
\hline go-lo $\beta-\mathbf{u m}$ & gu-lo $\beta$-um & 'language' \\
\hline$\varepsilon-p p \varepsilon \gamma-\mathbf{u l}$ & e-ppey-ul & ‘open’ \\
\hline
\end{tabular}

3.1.2. Backness harmony of high vowels. Eegimaa has a second type of vowel harmony, ${ }^{8}$ which targets only high vowels and accounts for the allomorphic variation between the prefixes $[\mathrm{I}]$ and $[\mathrm{\sigma}]$ on noun class prefixes. As Bassène (2007) shows (see also Bassene 2012), in prefixes with an initial labial consonant, such as those in (4), the vowel [I] occurs if the initial stem vowel is a front vowel $([\mathrm{I}]$ or $[\varepsilon]) .{ }^{9}$ In all other cases (see (5)), such as when the stem vowel is [a], the vowel of the noun class prefix is $[\mho]$.

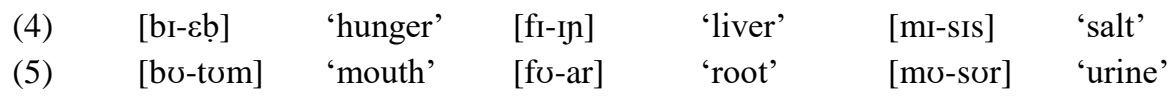

In prefixes with an initial coronal consonant, the prefix vowel is [ $]$ ] if the initial stem vowel is round ([ひ] or [o]) (see (7) below). In all other cases as exemplified in (6) the prefix vowel is [I].

\begin{tabular}{|c|c|c|c|c|c|c|}
\hline (6) & [jı-t:aja] & 'firefinch' & [nI-XInd] & 'plot of rice field' & [JI-rem] & 'small pond' \\
\hline (7) & [nv-ssu] & 'shame' & [jv-ppv] & 'bird' & {$[n v-t t o t]$} & 'cold' \\
\hline
\end{tabular}

3.2. Consonants and phonological processes. Eegimaa has seventeen phonemic consonants, all of which have geminate counterparts. Table 3 below presents an inventory (showing singleton consonants only).

Table 3. Consonant phonemes in Eegimaa (geminates not shown) ${ }^{10}$

8 I previously labelled this type of vowel harmony as involving height (Sagna 2008), but it is better described as involving backness as in Bassene (2012).

${ }^{9}$ These rules apply regardless of the [ATR] feature of the vowels of the roots.

${ }^{10}[\mathrm{x}]$ is an allophone of $/ \mathrm{k} /$ and $[\mathrm{r}]$ is an allophone of /d/ (see Sagna 2008). 


\begin{tabular}{llllll}
\hline & Bilabial & Labiodental & Alveolar & Palatal & Velar \\
\hline Plosives & $\mathrm{p} / \mathrm{b}$ & & $\mathrm{t} / \mathrm{d}$ & $\mathrm{c} / \mathrm{f}$ & $\mathrm{k} / \mathrm{g}$ \\
Nasal & $\mathrm{m}$ & & $\mathrm{n}$ & $\mathrm{j}$ & $\mathrm{j}$ \\
Fricative & & $\mathrm{f}$ & $\mathrm{s}$ & & \\
Lateral & & & $\mathrm{l}$ & & \\
Approximant & $\mathrm{w}$ & & & $\mathrm{j}$ & \\
\hline
\end{tabular}

Examples of minimal pairs, like / $\varepsilon$-pay/ 'shrine' and / $\varepsilon$-ppay/ 'fishing fence', / $\varepsilon$-fas/ 'drain' and $/ \varepsilon$-ffas/ 'know', illustrate the contrast between simple consonants and geminates. For a discussion of consonantal allophonic variations and geminates see Sagna (2008: 85-94 and 95-96).

Lenition of singleton consonants is a notable allophonic process in Eegimaa (see Hantgan-Sonko (2017) for an alternative analysis to the one proposed here). It includes the fricativization of voiceless plosives in word-initial position in some words, as in [фаjэm] 'my father', but also applies consistently in intervocalic and word-final position, as in $[\varepsilon \phi a \phi]$ 'dust'. Voiced plosives are always fricativized in intervocalic position, as in $[\mathrm{ba} \beta \varepsilon]$ 'around here'. In word-final position, they are devoiced, as in [Elab] 'boil'.

Geminates occur in their full form in intervocalic position, as in [ga-bbut] 'fishing rod' and [ja-ssaw] 'hunt/hunting'. In word-final position, geminates are phonetically simplified, as in [ $\varepsilon-\beta v t]$ 'deceive'. Their full forms are always restored in the case of suffixation, as in [nI- $\beta$ ttt-e] 'I deceived'.

Eegimaa NC clusters contain nasal consonants followed by homorganic voiced plosives, as exemplified in (8). Only voiced NC clusters are found in Eegimaa, in contrast with Jóola languages like Fogny (Sapir 1965), Karon (Sambou 2007), and Esuulaalu? (Sambou 1979), where voiceless NC clusters are attested.

$$
\text { [e-mbal }] \quad \text { 'fish net' } \quad[\varepsilon \text {-nd } \varepsilon] \text { 'thing' } \quad \text { [inje }] \quad \text { 'me' } \quad[\varepsilon \text {-bangal }] \text { 'shield' }
$$

As with geminates, NC clusters are also phonetically simplified in word-final position. For example, [ $\varepsilon$-famb] 'make noise' is realized as [ $\varepsilon$-fam] in normal speech.

Intervocalic voicing is another important phonological process in Eegimaa. It occurs in suffixation, where the consonants [t] and [x] change to [1] and [g] respectively when a suffix is added, generally with monosyllabic roots (Berndt 2003), as shown in (9) below:

$\begin{array}{llll}\text { Input } & & \text { Output } & \\ {[\varepsilon-\text { lat }]} & \text { 'refuse' } & {[\text { nI-lal- } \varepsilon]} & \text { 'I have refused' } \\ {[\varepsilon-f \circ x]} & \text { 'switch off' } & {[\text { nI-foy- } \varepsilon]} & \text { 'I have switched off' }\end{array}$

Eegimaa has suffixing reduplication, where reduplication marks perfective aspect (Sagna 2008: 96). Phonological processes which occur in reduplication include gemination, degemination, consonant loss, and prenasalization (see Sagna (2008: 95-96) and Hantgan et al. (2016) for an account of these processes based on mora preservation). Gemination is exemplified with the inflected verb

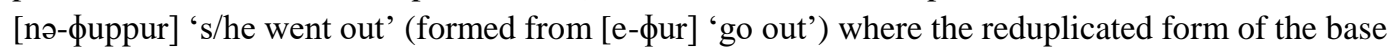

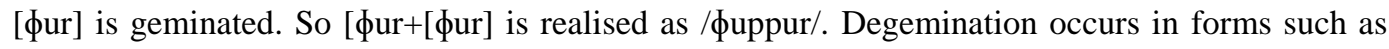


[na-llalat] 's/he hung', where the initial root geminate consonant [11] of the base [1lat] 'hang' is realised as a singleton consonant in the reduplicated form. So [1lat+llat] is realised /llalat/.

Consonant loss occurs in words such as in [na-lalat] 's/he refused' (a minimal pair with [na-llalat] 's/he hung'), where the final [t] is deleted from the base [lat] 'refuse', because consonant clusters other than NC clusters are banned in Eegimaa. In prenasalization, a word-final nasal assimilates and becomes homorganic with the reduplicated root-initial voiced consonant, as in

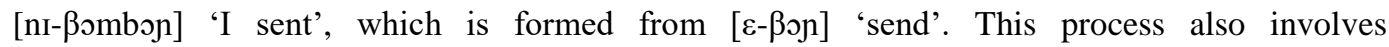
resyllabification of the final nasal consonant.

\section{Morphology}

4.1. Nominal morphology. The typical morphological structure of the noun in Eegimaa can be represented as in (10) below and exemplified with the noun ga-ñen-om 'my hand'. A noun is generally composed of a stem (in boldface), to which a prefix, traditionally referred to as a noun class marker, is attached. The stem may or may not be followed by a suffix.

$$
\begin{aligned}
& \text { Noun class-marker-stem-(suffix) } \\
& \text { 'plot of rice field' }
\end{aligned}
$$

Suffixes that attach to Eegimaa nouns include possessives (see $\$ 4.1 .3 .1$ below), the associative plural (see §4.1.3.2), and the inactualis (see $\$ 4.1 .3 .3$ ). They also include suffixes such as the 'life stage’ suffix (cf. §4.1.4.1) and the argument nominalization suffixes (§4.1.4.2). The discussion of nominal morphology begins with an overview of the Eegimaa noun class system.

4.1.1. The noun class system. Eegimaa has a noun class/gender system in which prefixes are used as noun class markers. The terms gender and noun class are often used interchangeably in the typological literature to refer to agreement-based systems of nominal classification where all nouns in the language are assigned to a class or gender based on agreement criteria (Welmers 1973; Greenberg 1978; Corbett 1991; Creissels 1999; 2001; Grinevald 2000; Aikhenvald 2000). As is typical for a Niger-Congo noun class system, there is no sex-based distinction in Eegimaa. In Eegimaa controller nouns trigger agreement on different agreement targets, as in examples (11) to (13) below, where agreement is marked on the definite determiner, and on the subject marker on verbs. $^{11}$

$$
\begin{array}{lcl}
\text { fu-jam } & \text { fafu } & \text { fú-ssum-e } \\
\text { CLfu-rainy.season(IV.SG) } & \text { IV.SG.DEF } & \text { IV.SG-be.good-CPL } \\
\text { 'The rainy season is good.' (ss20150820_NES) } &
\end{array}
$$

$\begin{array}{lcl}\text { fu-laor } & \text { fafu } & \text { fu-sassar } \\ \text { CLfu-rope(IV.SG) } & \text { IV.SG.DEF } & \text { IV.SG-break.REDUP } \\ \text { 'The rope is broken.' (ss060409_ab) } & \end{array}$

\footnotetext{
${ }^{11}$ In this paper, the source of the data presented in the examples is given in brackets beside the free translation. The data come from various genres, including conversation gathered through participant observation, songs, narratives, and elicitations. Simple example sentences come from my own native speaker intuitions.
} 
(13)

$\begin{array}{lcl}\text { gu-laor } & \text { gagu } & \text { gu-sassar } \\ \text { CLfu-rope(IV.PL) } & \text { IV.PL.DEF } & \text { IV.PL-break.REDUP } \\ \text { 'The ropes are broken.' (ss060409_ab) } & \end{array}$

The examples above illustrate syntactic or formal agreement where formal properties of the controllers are reflected on their agreement targets (Corbett 2006: 155). Formal agreement in gender and number generally comes with alliterative agreement between the nominal prefix and the agreement marker, though this is not always the case.

In the traditional approach to the analysis of Niger-Congo noun class systems, a singular and a plural form of a lexeme are assigned to different classes. Thus the singular noun fu-laor 'rope' and its plural counterpart gu-laor 'ropes' in examples (12) and (13) above belong to different classes. Singular nouns, like those in (11) and (12), belong to the same class because they trigger the same agreement markers on the same targets. Based on the traditional noun class approach in Niger-Congo languages, where singular and plural are treated as different classes, Eegimaa has 15 classes (Sagna 2008; Sagna 2010).

There are, however, more complex cases where there is no similarity between a nominal prefix and the corresponding agreement marker(s). This is exemplified in (14) with the noun ji-ggaj 'panther', which takes the singular prefix $j u-/ j i{ }^{12}$ and triggers agreement in the default Gender II singular $e-/ y$ - on all targets. Note that most nouns which take the singular prefix $j u-/ j i$ - normally trigger agreement markers of the form (ju-/ji-). Example (14) illustrates instances where nominal morphological class and agreement class do not match.

$$
\begin{array}{lc}
\text { ji-ggaj } & \text { yayu } \\
\text { CLju-panther(II.SG) } & \text { II.SG.DEF } \\
\text { 'The panther is cruel.' (ss040918_ñuhul) }
\end{array}
$$

\author{
é-lapulaput \\ II.SG-be.cruel.REDUP
}

The situation is more complex with hybrid nouns, i.e., nouns which trigger different agreement marking on different targets (see e.g. Corbett 2015). This is illustrated in (15), where the noun sú-jur 'young women', which belongs to the morphological class $b a-/ s u$-, triggers agreement in Gender II plural on the definite determiner, but the agreement marker on the verb is from a different gender, namely Gender I plural $(g u-)$. There is a mismatch in the gender feature but not in number, since the number value is plural everywhere.

$$
\begin{array}{llc}
\text { sú-jur } & \text { sasu } & \text { gu-ol-e } \\
\text { CLsu-girl(II.PL/I.PL) } & \text { II.PL.DEF } & \text { I.3PL-go.home-CPL } \\
\text { 'The girls/young women have gone home.' (ss11072013_MT) }
\end{array}
$$

Examples like (14) and (15) above illustrate the ambiguity in the use of the term 'class' in traditional descriptions of Niger-Congo noun classes. Corbett (1991: 45) points out that when it is said that a noun belongs to a particular class, it is unclear whether it is the morphological form of the noun or its agreement that is meant. He proposes a distinction between morphological classes, which are the

\footnotetext{
${ }^{12}$ Recall from Section 3.1.2 that the alternation between the vowels $/ i /$ and $/ u$ /in noun class prefixes is based on backness harmony of high vowels and does not reflect a change in nominal prefix.
} 
sets into which nouns are divided, and genders, which are the agreement classes of the targets (Corbett 1991: 47). ${ }^{13}$ The identification of genders/agreement classes in this approach is essentially based on the notion of agreement class defined in Corbett (1991: 147, 2007: 243) as a set of nouns which, whenever 'they stand in the same morphosyntactic form' (e.g. singular) and 'occur in the same agreement domain' (e.g. the noun phrase) and 'have the same lexical item as agreement target' (e.g. adjective), have the same morphological realization on their targets. This is the approach I use in this paper. $^{14}$

According to the gender approach, the nouns ji-ggaj 'panther' in (14) above and e-joba 'dog' in (16) below, which belong to different morphological classes as evidenced by the prefixes they take, belong to the same gender class, since they trigger the same agreements in the singular and the plural (compare (14) above with (18) below, and (16) with (17)).

\begin{tabular}{|c|c|c|}
\hline e-joba & yayu & é-lapulaput \\
\hline CLe-dog(II.SG) & II.SG.DEF & II.SG-be.cruel.REDUP \\
\hline \multicolumn{3}{|l|}{ 'The dog is cruel.' } \\
\hline su-joba & sasu & sí-lapulaput \\
\hline CLsu-dog(II.PL) & II.PL.DEF & II.PL-be.cruel.REDUP \\
\hline \multicolumn{3}{|l|}{ 'The dogs are cruel.' } \\
\hline si-ggaj & sasu & sí-lapulaput \\
\hline CLsu-panther(II.PL) & II.PL.DEF & II.PL-be.cruel.REDUP \\
\hline
\end{tabular}

Based on the approach to gender in which agreement classes are considered in pairs, Eegimaa has ten main genders which are presented in Table 4 below, and one inquorate gender (V/IV), i.e., a gender with very few members (Corbett 1991).

\footnotetext{
${ }^{13}$ The separate treatment of morphological classes in this paper, following Corbett (1991), is also comparable with the 'paradigm approach' (see Cobbinah 2013; Watson 2015; Pozdniakov 2010). For simplicity I present most examples using the singular forms.

${ }^{14}$ With this approach, it is assumed that number is primarily an inflectional grammatical feature. The argument that number as expressed in noun class systems is derivational has been proposed in a number of works on Niger-Congo noun class systems (e.g. Mufwene 1980; Schadeberg 2001; Cobbinah \& Lüpke 2014). I leave this issue for future research, where the criteria to be used for arguing in favour or against the inflectional or derivational properties of number can be investigated in detail.
} 
Table 4. The agreement classes of the Eegimaa noun class/gender system

\begin{tabular}{|lllll|llll|}
\hline Gender & SG & & & & PL & & & \\
\hline & DEM & PRO & ADJ & VP & DEM & PRO & ADJ & VP \\
\hline I & $m-$ & $m-$ & $a-$ & $(n) a-$ & $b u g-$ & $b u g-$ & $g u-$ & $g u-$ \\
\hline II & $y-$ & $y-$ & $e-$ & $e-$ & $s-$ & $s-$ & $s u-/ s i-$ & $s u-/ s i-$ \\
\hline III & $b-$ & $b-$ & $b u-/ b i-$ & $b u-/ b i-$ & $w-$ & $w-$ & $u-$ & $u-$ \\
\hline IV & $f-$ & $f-$ & $f u-/ f i-$ & $f u-/ f i-$ & $g-$ & $g-$ & $g u-$ & $g u-$ \\
\hline V/IV & $g-$ & $g-$ & $g u-$ & $g u-$ & $g-$ & $g-$ & $g u-$ & $g u-$ \\
\hline V & $g-$ & $g-$ & $g u-$ & $g u-$ & $w-$ & $w-$ & $u-$ & $u-$ \\
\hline VI & $j-$ & $j-$ & $j u-/ j i-$ & $j u-/ j i-$ & $m-$ & $m-$ & $m u-$ & $m u-$ \\
\hline VII & $\tilde{n}-$ & $\tilde{n}-$ & $\tilde{n} u-/ \tilde{n} i-$ & $\tilde{n} u-/ \tilde{n} i-$ & $w-$ & $w-$ & $u-$ & $u-$ \\
\hline VIII & $t-$ & $t-$ & $t u-/ t i-$ & $t u-/ t i-$ & & & & \\
\hline IX & $d-$ & $d-$ & - & $d u-/ d i-$ & & & & \\
\hline X & - & $n-$ & - & & & & & \\
\hline
\end{tabular}

4.1.2. Noun class semantics. There is much controversy as to whether noun class systems are semantically motivated synchronically in Niger-Congo languages. The scepticism surrounding noun class semantics is often fuelled by observations that nouns in semantic fields such as body parts and plants are found in different classes. Recent research has shown, sometimes using Prototype Theory, that semantic categorization is synchronically active in noun class systems in both Bantu (e.g. Contini-Morava 1997) and Atlantic languages (e.g. Breedveld 1995). In this section I present aspects of my previous findings on Eegimaa noun class semantics (see Sagna 2008; Sagna 2012) ${ }^{15}$ by arguing the following:

- Noun classes are associated with semantic content (Sagna 2011a: 2).

- Shape and size are encoded in the Eegimaa noun class system. ${ }^{16}$ This is shown by the integration of loanwords, the classification of body parts and the formation of augmentatives.

- Culture-specific principles also play a role in the semantic categorization of nouns in Eegimaa.

4.1.2.1. Shape-based classification of Eegimaa nouns. Eegimaa nouns denoting round and flat entities such as objects, body parts, and parts of things such as plants are assigned to the classes $f u$-/gu- and $g a-/ u$ - (see (19) and (20) respectively).

$\begin{array}{llll}\text { fu-la } & \text { 'buttocks' } & \text { fu-how } & \text { 'head' } \\ \text { fu-ttun } & \text { 'penis' } & \text { gu-ffot } & \text { 'testicles' } \\ \text { fi-lej } & \text { 'tail' } & \text { fu-boy } & \text { 'thigh' }\end{array}$

\footnotetext{
${ }^{15}$ See these works also for an account of the different semantic categories for humans and liquids.

${ }^{16}$ See Cobbinah (2013) and Watson (2015) for similar findings in Baïnounk Gubëeher and Jóola Kujireray respectively.
} 
(20)

$\begin{array}{llll}\text { ga-rab } & \text { 'cheek' } & \text { ga-nnu } & \text { 'ear' } \\ \text { ga-lefej } & \text { 'palm' } & \text { ga-pol } & \text { 'skin' } \\ \text { ga-toj } & \text { 'leaf' } & \text { ga-pal } & \text { 'bark' }\end{array}$

Nouns denoting fruits take the prefix pair $f u-/ g u$ - because of the round shape of fruits, not because there is a class for fruits. This is illustrated with the tree-fruit distinctions in (21).

$\begin{array}{llll}\text { bú-kkaju } & \text { 'cashew tree' } & \text { fú-kkaju } & \text { 'cashew fruit' } \\ \text { bu-mangu } & \text { 'mango tree' } & \text { fu-mangu } & \text { 'mango' } \\ \text { bu-ppapa } & \text { 'papaya tree' } & \text { fu-ppapa } & \text { 'papaya fruit' }\end{array}$

4.1.2.2. Three semantically distinct augmentatives. There are three semantically distinct augmentatives in Eegimaa. They are formed by class shift, as is typical in North-Central Atlantic and Bantu noun class systems (Di Garbo 2014: 147), and express semantic differences in size and also shape. The prefix pair $g a-/ u$ - is used to derive augmentative and derogatory meanings, as illustrated in (22).

$\begin{array}{llll}\text { fu-how } & \text { 'head' } & \text { ga-how } & \text { 'big/ugly head' } \\ \text { fí-rerum } & \text { 'tongue' } & \text { gá-rerum } & \text { 'big/ugly/wide tongue' } \\ \text { bu-tum } & \text { 'mouth' } & \text { ga-tum } & \text { 'big/ugly/wide mouth' }\end{array}$

Augmentatives formed with the prefix pair $f u$ - $/ g u$ - express roundness (fatness or thickness) and are the only types of augmentatives where size and shape are combined (see example (23)).

$\begin{array}{llll}\text { ga-ñen } & \text { 'hand' } & \text { fi-ñen } & \text { 'big/fat hand' } \\ \text { a-ññil } & \text { 'child' } & \text { fi-ññil } & \text { 'big/fat child' } \\ \text { ga-hait } & \text { 'paper' } & \text { fu-hait } & \text { 'big/thick sheet of paper' }\end{array}$

The third augmentative category describes entities of enormous size (see (24)) using the prefix pair bu-/u-.

$\begin{array}{llll}\text { fu-how } & \text { 'head' } & \text { bu-how } & \text { 'enormous head' } \\ \text { é-ñundu } & \text { 'nose' } & \text { bú-ñundu } & \text { 'enormous nose' } \\ \text { é-fulum } & \text { 'backside' } & \text { bú-fulum } & \text { 'enormous backside' }\end{array}$

4.1.2.3. Loanwords and their semantic integration. Sagna's (2008) study of the integration of 133 loanwords showed that there are three ways by which loanwords are integrated into Eegimaa:

a) Phonological integration, as with si-garet 'cigarette', which takes the prefix si- based its similarity with the initial syllable of the loanword 'cigarette'.

b) Default integration, whereby most borrowed nouns are put into the default class.

c) Semantic integration with shape being the main criterion

Examples of the third type of integration are loanwords in the morphological class $f u$ - $/ g u$ - (15.8\% of loanwords) denote prototypically round (spherical) or less round objects (see (25)). Those having 
a clear flat and thin shape are directly integrated into the morphological class $\mathrm{ga}_{-} / \mathrm{u}^{-17}(22.6 \%)$ (see (26)). Other semantically-based integrations, not discussed here due to space restrictions (Sagna 2008; 2012 for a detailed account), include nouns of human denotation (11.3\%), trees (5.3\%), and paired entities (1.5\%). Note that loanwords assigned to the default class make up $43.6 \%$ of all borrowed words.

\begin{tabular}{|c|c|c|c|}
\hline fu-balon & 'football' & fú-ru & 'wheel' \\
\hline fú-ttuyo & 'pipe’ & fu-vvolan & 'steering wheel' \\
\hline fu-rulo & 'roll' & fi-serkal & 'rim’ \\
\hline ga-kkart & 'card' & ga-pposter & 'poster' \\
\hline ga-planche & 'plank' & ga-bbache & 'tarpaulin' \\
\hline ga-ffay & 'sheet of paper' & ga-pparabrise & 'windscreen' \\
\hline
\end{tabular}

4.1.2.4. The semantics of collectives. The prefix $b a$ - is used productively as a 'diminutive collective' with count nouns (including loanwords) to describe assemblages of small entities viewed as a unit, as exemplified in (27). ${ }^{18}$

$$
\begin{aligned}
& \text { ba-abut bu-taf-ol } \\
& \text { CLba-ant(III.SG) III.SG-sting-3sG.OBJ } \\
& \text { 'A group of small ants stung him.' }
\end{aligned}
$$

Another collective category is the unproductive 'swarm collective', which is expressed by the combination of the prefix $f a$ - with nouns denoting insects such as bees, locusts, and ants that live in swarms (see example (28)).

$$
\begin{array}{ll}
\text { fa-abut } & \text { fu-taf-ol } \\
\text { CLfa-ant(IV.SG) } & \text { IV.SG-sting-3sG.OBJ } \\
\text { 'A swarm of ants stung him.' }
\end{array}
$$

The third kind of collective marker is expressed (productively) by means of the prefix $e$ - with nouns denoting humans (including loanwords) who constitute a cohesive unit (a colony), as exemplified in (29). These include language communities, identity groups, people of the same origins, and professionals in modern jobs, e.g. e-muse 'teachers'. Nouns denoting human colonies in Eegimaa are hybrid nouns, in the sense that they trigger different gender or number feature values in the plural. They exemplify culture-bound classifications and their 'multiple agreements' reflect multiple semantic categorizations (see Sagna 2012 for details).

\footnotetext{
${ }^{17}$ Consonant clusters are not permitted in Eegimaa. In these examples, the nouns containing clusters are not fully integrated. Their transcription represents the way they are pronounced by the bilingual French speakers from whom the data were collected.

${ }^{18}$ Collective markers are also markers of basic number values. They are glossed as singular because in most of their occurrences the prefixes are used as singular markers. Note that I do not use the term 'triad' (see Cobbinah 2013; Watson 2015) because not all nouns expressing collective meaning are involved in singular/plural/collective relations.
} 
(29)

$\begin{array}{llll}\text { é-jjola } & \text { yayu } & \text { gu-añ-e-añ } & \text { e-mmano } \\ \text { CLe-jóola(II.SG) } & \text { II.SG.DEF } & \text { I.3PL-cultivate-HAB-REDUP } & \text { cLe-rice(II.SG) }\end{array}$

The Jóola people grow rice.'

The prefix $e$ - is also used as a collective marker for nouns denoting colonizing plants, which grow as colonies as in (30), but these plant-denoting nouns never occur as hybrids.

$$
\begin{array}{lll}
\text { e-rarah } & \text { yayu } & \text { e-çel-e } \\
\text { CLe-Ipomea.asarifolia(II.SG) } & \text { II.SG.DEF } & \text { II.SG-die-CPL } \\
\text { 'The Ipomea asarifolia } \text { colony of grass has died.' (ss20040412_AS) }
\end{array}
$$

To summarize this section, semantics is still productive in Eegimaa noun classes. Where semantic categorization is still relevant, the classification of nouns is based on shape and size, as seen with loanwords.

\subsubsection{Nominal inflectional suffixation}

4.1.3.1. Possessive suffixes. Possessive suffixes attach to the possessum when the possessor is human, as shown in (31). Eegimaa distinguishes inclusive and exclusive first person plural.

$\begin{array}{llll}\begin{array}{l}\text { Singular } \\ \text { a-ppal-om }\end{array} & \text { 'my friend' } & \begin{array}{l}\text { Plural } \\ \text { a-ppal-olal } \\ \text { a-ppal-oli }\end{array} & \begin{array}{l}\text { 'our friend (INCL)' } \\ \text { 'our friend (EXCL)' }\end{array} \\ \text { a-ppal-i } & \text { 'your friend' } & \text { a-ppal-ul } & \text { 'your friend' } \\ \text { a-ppal-ol } & \text { 'his/her friend' } & \text { a-ppal-il } & \text { 'their friend' }\end{array}$

With non-human possessors, the possessive pronoun $C L-o$, which shows agreement in gender and number with the antecedent noun, is used as a possessive marker. Example (32) shows a full NP, which is replaced by a pronoun in example (33).

$\begin{array}{lll}\text { bu-roy } & \text { sí-be } & \text { sasu } \\ \text { CLbu-life(III.SG) } & \text { CLsu-cow(II.PL) } & \text { II.PL.DEF } \\ \text { 'The life of the cows' } & & \end{array}$

$\begin{array}{ll}\text { bu-ron } & \text { S-O } \\ \text { CLbu-life(III.SG) } & \text { II.PL-PRO } \\ \text { 'Their (non-human) life' }\end{array}$

4.1.3.2. The associative plural suffix $-\boldsymbol{i}$. Eegimaa has an associative plural suffix, which attaches to proper names (see (34)), personified non-human entities (35), and kin terms (36). The typical meaning of associative plurals is ' $\mathrm{X}$ and associates' (Daniel \& Moravcsik 2013; Corbett 2000), where $\mathrm{X}$ stands for the main referent of a heterogeneous group. In (35), for example, the group is composed of a named animal and other animals of different kinds. Eegimaa singular nominals, which take the associative plural, trigger plural agreement, as can be seen in examples (34) to (36). 
Ámbulat-i gu-mund-e gu-jow

Ámbulat(I.SG)-ASSOC I.3PL-do.first-CPL I.3PL-go

'Ámbulat and his companions were the first to go.'(Part-Obsv-2015)

$\begin{array}{lllll}\text { Já-nuhuren-i } & \text { googe } & \text { ban } & \text { gu-kkan } & \text { bu-ffutor } \\ \text { CLja-animal(I.SG)-ASSOC } & \text { I.3PL.say.CPL } & \text { IMM.FUT } & \text { I.3PL-do } & \text { CLba-association(III.SG) } \\ \text { 'Animal and his companions decided that they would form an association.'(Jibas2003) }\end{array}$

$\begin{array}{lll}\text { pay-om-i } & \text { gu-mund-e } & \text { gu-jow } \\ \text { father(I.SG)-1sG.POSS-ASSOC } & \text { I.3PL-do.first-CPL } & \text { I.3PL-go } \\ \text { 'My father and his companions } & \text { were the first to go.' } & \end{array}$

4.1.3.3. The inactualis nominal TAM suffix -en. The suffix -en combines with nouns (and also verbs, as discussed0 below) and functions as a nominal TAM marker expressing the meaning of 'past' (see Nordlinger and Sadler 2004 for a typology of nominal tense systems). For example, it can attach to a noun like yay 'house', as in (37), to indicate a 'former' function.

$$
\begin{array}{ll}
\text { dáuru } & \text { y-an-en } \\
\text { this } & \text { CLe-house-INACT }
\end{array}
$$

'This is a former house.'

In possessive constructions, it attaches to the head (the possessum) and expresses an alienability contrast (Haspelmath, To appear) with the meaning of 'former'. With kinship terms, it combines with nouns denoting relatives by marriage (see 38a), where the relationship can be terminated, but not with consanguineal kinship terms as in $38 \mathrm{~b}$. The only way $38 \mathrm{~b}$ can be interpreted is in a joking context.

$$
\begin{aligned}
& \text { a. aar-en Nestor } \\
& \text { [CLa-]wife-INACT, Nestor } \\
& \text { 'Nestor's ex-wife' }
\end{aligned}
$$
b. ??a-ññol-en
Nestor
CLa-child- INACT
'Nestor's former child.'

The inactualis is not acceptable with body part terms even in the case of amputation (see $39 \mathrm{~b}$ ). It is acceptable, however, in constructions where a relationship of ownership can be terminated, as in 39a. Without the -en suffix, 39a would mean 'Nestor's house'.
a. y-ay-en Nestor
CLe-house-INACT Nestor
'Nestor's former house'
b. *ga-ñen-en Nestor Clga-hand-INACT Nestor 'Nestor's former hand'.

\subsubsection{Nominal suffixal derivation}

4.1.4.1. The life stage suffix $-\boldsymbol{e}$. The suffix $-e$ is an unproductive derivational suffix, which has been found on the three nouns presented in (40), used to denote life stages. 
(40)

$\begin{array}{ll}\text { fi-ññil-e } & \text { 'childhood' } \\ \text { fu-pput-e } & \text { 'early childhood' } \\ \text { fu-ffan-e } & \text { 'adulthood' }\end{array}$

It is productive when used with stative verbs (see (41)) to derive abstract nouns describing a state or condition that the verb refers to.

$$
\begin{array}{ll}
\text { ma-pul-e } & \text { 'rot/that which is rotten' } \\
\text { má-sup-e } & \text { 'hot part/that which is hot' } \\
\text { má-ssum-e } & \text { 'good//that which is good' }
\end{array}
$$

4.1.4.2. Argument nominalization. The main argument nominalizations (see Sagna (2008) for details) include agentive nouns formed with the suffix $-a$ (42); instrumental nominalizations formed

\begin{tabular}{|c|c|c|c|c|}
\hline (42) & á-kkuj-a & 'wrestler' & a-rem-a & 'drinker' \\
\hline (43) & fi-hiç-um & 'pen' & fú-rovv-um & 'seat' \\
\hline (44) & ba-lluj-er & 'manner of looking' & ba-bog-er & 'manner of dancing' \\
\hline 4 & e-ssum-ay & ‘joy’ & ma-mandin-ay & 'the Mandinka way' \\
\hline
\end{tabular}
with the suffix -úm (43)); manner nominalizations formed with the circumfix ba-...er (44); and abstract noun formation with the suffix -ay (cf. (45)).

4.2. Non-finite verbs and their overt classification. Eegimaa non-finite verbs are formed using several of the noun class prefixes found on nouns. This phenomenon is illustrated in (46) and (47), which show that subject markers like $n a$ - and the noun class prefix $b a$-alternate in the same slot.

$\begin{array}{llll}\text { Appu } & \text { na-vvu-e } & \text { e-ssal } & \text { yayu } \\ \text { Appu(I.SG) } & \text { REAL.I.3sG-sweep-CPL } & \text { CLe-hall(II.SG) } & \text { II.SG.DEF } \\ \text { 'Appu has swept the village hall.' (ss20140404_AmT) } & \end{array}$

$\begin{array}{lllll}\text { Appu } & \text { na-ban-e } & \text { ba-vvu } & \text { e-ssal } & \text { yayu } \\ \text { Appu(I.SG) } & \text { REAL.I.3sG-finish-CPL } & \text { CLba-sweep } & \text { CLe-hall(II.SG) } & \text { II.SG.DEF } \\ \text { 'Appu has finished sweeping the hall.' (ss20140404_AmT) } & & \end{array}$

In addition to taking different types of prefixes, Eegimaa non-finites differ from their finite counterparts in that TAM markers can be found only on finite verbs, as in (46), but not on non-finite verbs. Syntactically, non-finite verbs can take objects just like their finite counterparts as shown in examples (48) and (49), but non-finite verbs occur after complement-taking predicates and cannot function as the main verbs in a clause, while the finite counterparts can.

We can see the use of prefixes with both nouns and verbs in (48) and (49). The prefix $e$ - is attached to the non-finite verb e-kkotten 'smoke out' in (48), and to the noun $e$-ssal 'hall' in (49). Likewise, the prefix $b a$-attaches to a noun in ba-hola 'midges' (48), whereas in (49) it is found with the non-finite verb $b a-v v u$ 'sweep'.

$$
\begin{aligned}
& \text { Appu umu ni e-kkotten ba-hola babu } \\
& \text { Appu(I.SG) COP.I.SG.MED PREP CLe-smoke.out CLba-midge(III.SG) III.SG.DEF } \\
& \text { 'Appu is chasing midges with smoke.' }
\end{aligned}
$$




$\begin{array}{llll}\text { Appu } & \text { na-ban-e } & \text { ba-Vvu } & \text { e-ssal } \\ \text { Appu(I.SG) } & \text { REAL.I.3sG-finish-CPL } & \text { CLba-sweep } & \text { CLe-hall(II.SG) } \\ \text { 'Appu has finished sweeping a hall.' (ss20140404 AmT) } & \end{array}$

In (50) and (51), the prefixes $m a$ - and $g a$ - are used with the non-finite verbs 'drink' and 'rake up' respectively. Note that the combination of prefixes with different roots on non-finite verbs is lexically determined. The prefixes $m a$ - and $g a$ - cannot alternate on the same verb. ${ }^{19}$

$\begin{array}{lllll}\text { Nestor } & \text { na-kke } & \text { Gájjigay } & \text { ma-rem } & \text { ga-jjo } \\ \text { Nestor(I.SG) } & \text { REAL.I.3sG-go } & \text { Gájjigay } & \text { CLba-drink } & \text { CLga-mead(v.SG) } \\ \text { 'Nestor has gone to Gájjigay to drink } & \text { mead.' (Songs_Pop) } & \end{array}$

\begin{tabular}{|c|c|c|c|c|}
\hline aare-aw & na-kkumasi-e & ga-rato & ma-fos & mamu \\
\hline [CLa]woman-I.SG.DEF & REAL.I.3SG-begin-CPL & CLga-rake_up & CLma-weed(VI.PL) & VI.PL.DEF \\
\hline
\end{tabular}

Typologically, non-finite verbs occur after complement-taking predicates such as desiderative ('want') verbs and phrasal-aspectual verbs ('start, continue, finish') (Noonan 2007; Haspelmath 1989; Koptjevskaja-Tamm 1993). They have both verbal properties, as in (52), where ja-ssaw 'hunt/hunting' occurs as a verb taking an indefinite plural object; and nominal properties, as in (53), where it occurs in argument position as a subject and triggers gender and number agreement on the verb.

\begin{tabular}{|c|c|c|c|}
\hline Appu & na-hal-e & ja-ssaw & si-tahalla \\
\hline $\mathrm{Appu}(\mathrm{I} . \mathrm{SG})$ & REAL.I.3sG-stop-CPL & CLja-hunt & CLsu-gazelle(II.PL) \\
\hline \multicolumn{4}{|c|}{ 'Appu has stopped hunting gazelles.'(ss20140404_AmT) } \\
\hline googe & ja-ssaw & nahi & ji-lalat \\
\hline I.3PL.say.CPL & CLja-hunt(VI.SG) & НАB & VI.SG-refuse.REDUP \\
\hline
\end{tabular}

There are possible alternations between prefixes on the same verbal stem. These alternations are attested only between the prefix $e$ - (the default marker with nouns) and the other prefixes, for example $b a-, g a-$, and $m a-$. In a broad characterization of these alternations, I argue (following Sagna (2013)) using Hopper and Thompson's (1980; see also Næss 2007) terms, that when alternations are permissible, that the prefix $e$ - is used to express high transitivity (e.g. definiteness, telicity, specificity, punctuality), whereas the other prefixes like $b a-, g a-, m a$ - or $j a$ - are preferred in the expression of low transitivity (e.g. indefiniteness, atelicity, non-specificity, durativity). In example (54), the non-finite verb takes the prefix $e$ - and a definite singular object that refers to a specific entity. In general, the prefix $e$ - is strongly preferred for the description of events which are construed

\footnotetext{
${ }^{19}$ The use of several markers to form non-finite verbs ('infinitives' or 'verbal nouns', depending on the author) has been reported in Jóola Kwaatay (Kennedy 1964), Jóola Fógny (Sapir 1965), Eegimaa (Bassène 2007; Sagna 2008), and in neighbouring languages like Baïnounk Gubëeher (Cobbinah 2013). This suggests that this phenomenon may be an areal feature.
} 
as individuated and as having an inherent endpoint. In this example, the activity has a built-in goal, which will be reached when the woman has weeded the field in question from beginning to end. In example (55), on the other hand, the prefix $b a$-is used with the non-finite verb in an objectless clause. Here the event is not individuated; there is no built-in endpoint to the activity described by the verb. So the activity may be carried out on any number of fields for an undefined period.

$$
\begin{aligned}
& \text { aare ahu na-kkumasi-e é-fosul ga-al gagu } \\
& \text { [CLa]woman(I.SG) I.SG.DEF REAL.I.3SG-begin-CPL CLe-weed CLga-furrow(V.SG) V.SG.DEF }
\end{aligned}
$$

$\begin{array}{llll}\text { aare } & \text { ahu } & \text { na-kkumasi-e } & \text { bá-fosul } \\ \begin{array}{ll}\text { [CLa]woman(I.SG) } & \text { I.SG.DEF }\end{array} & \text { REAL.I.3sG-begin-CPL } & \text { CLba-weed } \\ \text { 'The woman has begun weeding.' (ss20130819_RB) } & \end{array}$

The fact that several noun class markers are used to form non-finite verbs suggests a morphological classification of these non-finite verbs. I argue that Eegimaa has a system of overt verb classification, which is defined as a phenomenon whereby 'verbs and/or the events they refer to are overtly categorized into types by grammatical means' (McGregor 2002: 1-2).

The type of overt verb classification found in Eegimaa is a system that operates at two levels. The first level is shown by alternations between the prefix $e$ - and other prefixes like $b a$ - and ja-. Generally, high transitivity (e.g. individuation) is expressed using the prefix $e$-, while low transitivity (e.g. non-individuation) is expressed with prefixes like $b a-$. The second level may be called 'within low transitivity' and reflects a categorization of different kinds of events (SchultzeBerndt \& Sagna 2010; see also Cobbinah 2013; and Watson 2015 for similar conclusions). On this level, the different prefixes used with non-finite verbs indicate different semantic categories. For example, the prefix $b a$-is used to express multiplicity of actions and participants, showing parallels with its use as a diminutive collective marker in the nominal domain to express multiplicity of entities. As for the prefix ma-, this is generally used with verbs that refer to unbounded events such as bodily processes (e.g. verbs of ingestion and digestion). The categorization of unbounded events with the prefix $m a$ - parallels that of non-count nouns denoting unbounded entities like liquids and masses in the nominal domain, as argued in Schultze-Berndt \& Sagna (2010) and Sagna (2017).

4.3. Verbal morphology. The minimal structure of the verbal word in Eegimaa is prefix+stem, as in the imperative $u$-tin 'eat $(2 \mathrm{SG})$ '. The maximal structure of verb is broadly characterized in the position class diagram in $\$ 4.3 .1$ below.

4.3.1. Verbal morphology schema. The diagram presented here is not intended as a complete fine-grained presentation of the suffix slots. Rather it is provided to give the reader a sense of the complex structure of the verbal morphology. All the slots presented here can be filled on a single verb. Note that Safir and Bassene (2014) provide a different and more detailed analysis of the affixordering rules in Eegimaa.

Table 5. Broad characterization of the morphological structure of the Eegimaa verb sm $\mid$ Verb root $\mid$ Deriv1 $\mid$ Deriv2 $\mid$ Deriv3 $\mid$ tam $\mid$ ven $\mid$ neg $\mid$ om/pass $\mid$ redup 
The diagram shows that in the finite form of the verb, the verb root is preceded by the subject marker, and followed by different verb extensions. As shown in (56) and (57), the verb root (in boldface) is followed by the causative suffix -en, which fills a slot (Deriv1) that can also be occupied by the middle suffix $-o$. The second slot (Deriv2), which is filled by the reciprocal suffix -or in the examples given here, can also be filled by the reflexive -oro. It is followed by the 'anticipative' suffix, which occurs in the Deriv 3 slot and which describes an event which took place earlier, before a given time. The TAM slot is filled by suffixes such as the inactualis/non-factual marker -en and the completive marker $-e$. The 'VEN' slot is filled by the venitive suffix - $u l$ 'towards the speaker' or the venitive completive -ulo 'completed before moving towards the speaker'. In a negation construction, as in example (56), the negative suffix -at must follow the venitive if they co-occur, followed by the passive suffix $-i$. Depending on the context, the object marker can occur in the slot where the passive is found.

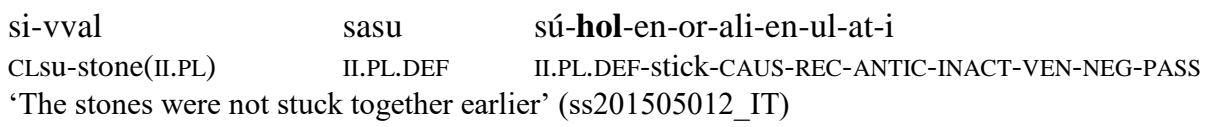

In case of verb reduplication in an affirmative clause, the venitive or venitive completive can be followed by an object marker like -so and the reduplicated stem (e.g. -hol-en-or 'stick together'), with the Deriv1 and Deriv2 slots also filled. This is exemplified in (57), where the reduplicated verbal stem is in boldface.

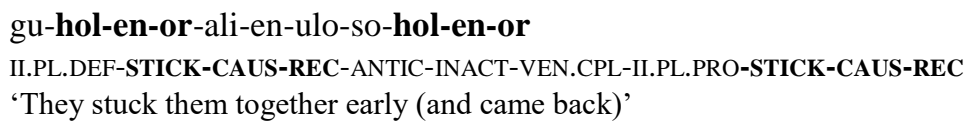

As pointed out above, the examples above are only intended to show the complexity of Eegimaa verbal morphology rather than provide a full account of the structure of the verb.

\subsubsection{Verbal prefixes}

4.3.2.1. Subject markers. In their finite form, verbs take subject markers, which, in the third person, show agreement in gender, number and person with an antecedent noun that may or may not be present in the clause (see (58) and (59)).

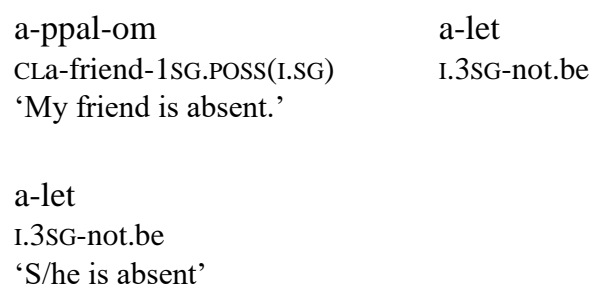




\subsubsection{Verb extensions}

4.3.3.1. Summary of verb derviational suffixes. The most common Eegimaa derivational suffixes are summarized in Table 6 . The verb extensions presented here include those used in valence changing operations like the passive, which, strictly speaking, may not be classed as derivational because they do not create new lexemes (Spencer 2013).

Table 6. The most common verb extensions

\begin{tabular}{lllll}
\hline Extensions & Label & Examples & Gloss & Translation \\
\hline -úl & Venitive & é-pur-ul & CLe-go.out-VEN & 'come out' \\
-ul & Reversative & e-gub-ul & CLe-cover-REV & 'uncover' \\
-úm & Directive & é-jow-um & CLe-go-DIR & 'go through' \\
-áli & Anticipative & é-kkan-ali & CLe-do-ANTIC & 'do early' \\
-akken & Repetitive & é-ssil-akken & CLe-cook-REP & 'cook another time' \\
-en & Causative & e-rokk-en & CLe-work-CAUS & 'make work' \\
-o & Middle & e-jal-o & CLe-unfasten-MID & 'unfasten' \\
-or & Reciprocal & bu-jug-or & CLbu-see-RECIP & 'see each other' \\
-oro & Reflexive & e-kkan-oro & CLe-do-REFL & 'do for oneself' \\
-i & Passive & e-saen-i & CLe-burn-PASS & 'it hast been burnt' \\
\hline
\end{tabular}

4.3.3.2. Pluractional verbs. Eegimaa has an unproductive derivational strategy of reduplication, as exemplified in (60) where the stems are in boldface. The derived reduplicated lexemes are 'pluractional' verbs which describe a multiplicity of actions (Newman 1990: 53-54).

$\begin{array}{llll}\text { e-tey } & \text { 'run' } & \text { e-teteyor } & \text { 'run from place to place' } \\ \text { e-ber } & \text { 'laugh' } & \text { e-bebberor } & \text { 'spend time laughing' } \\ \text { e-maen } & \text { 'touch' } & \text { e-mamaen } & \text { 'palpate' }\end{array}$

4.3.3.3. Derivation by stem alternation and prefix change. An interesting but as yet unstudied aspect of the lexicons of Jóola languages is a derivational process that combines [ATR]-based stem alternation and prefix change as exemplified in Table 7. All the verbs in the "-ATR realization" section of the table take the prefix $e$ - as a marker of non-finiteness. Nouns or action/state nominalizations like those on the right-hand side of the table ("+ATR realization") are derived from the same verbal roots through a process that includes a change in prefix and a modification of the stem vowels from [-ATR] to [+ATR], as indicated by the acute accent on the first vowel of the derived words. This process cannot be captured by the synchronic phonological rules discussed in $\$ 3.1 .1$ above, nor by any morphological rule of concatenation. I leave this issue for future research. 
Table 7. Alternations between [+ATR] and [-ATR] in derivations

\begin{tabular}{ll|l}
\hline -ATR realization & +ATR realization \\
\hline e-emor 'to meet' & bí-emor 'to \\
e-yab & 'to receive/to marry' & bú-yab 'to marry/marrying' \\
e-yab & 'to receive/to marry' & bú-oh 'to get married/marriage' \\
e-eh & 'to say' & bú-ogor 'to quarrel/quarrelling' \\
e-eh & 'to say' & sí-ccenor 'debating' \\
e-ccenor $\quad$ 'to debate/fight over & já-omen 'gathering cattle' \\
e-omen $\quad$ 'to assemble' & bú-llar 'work/job' \\
e-llar & 'to work' &
\end{tabular}

4.3.3.4 Noun to verb causative formation with -en. The causative suffix -en can also be used less productively with noun stems to derive verbs with the meaning of 'make an X' or 'put X on', as in (61).

$$
\begin{array}{llll}
\text { á-vvi } & \text { 'king' } & \text { já-vvi-en } & \text { 'enthrone king' } \\
\text { é-lluh } & \text { 'mud' } & \text { é-llutt-en } & \text { 'put mud on' }
\end{array}
$$

4.3.3.5. The polysemous verbalizer -et. Verbs can be derived from nouns using the productive verbalizer - et. The meanings of the derived forms include 'collect X' or 'be X', as illustrated in (62).

$$
\begin{array}{llll}
\text { e-son } & \text { 'mad person/fool' } & \begin{array}{l}
\text { bu-son-et } \\
\text { ga-mangu-et }
\end{array} & \begin{array}{l}
\text { 'be a fool' } \\
\text { fu-mangu }
\end{array} \\
\text { 'mango' } & \text { 'pick up/collect mangoes' }
\end{array}
$$

4.3.4. Survey of the TAM system. The tense-aspect-mood marking of Jóola languages in general is very poorly understood, and its interaction with lexical aspect has never been subject to any investigation. In this section I provide a brief survey of the Eegimaa TAM system.

4.3.4.1. The completive - $\boldsymbol{e}$. The completive -e (l'accompli in (Bassène 2007)) combines with dynamic verbs to describe events that are carried out thoroughly and to completion, and in which the object is totally affected (Bybee et al.1994). This is illustrated in (63), where the 'baobab tree' is totally affected by the action carried out (to completion) by the subject-agent Jiñappu.

$\begin{array}{llll}\text { Jiñappu } & \text { na-bel-e } & \text { bu-bah } & \text { babu } \\ \text { Jiñappu(I.SG) } & \text { REAL.I.3SG-fell-CPL } & \text { CLbu-baobab(III.SG) } & \text { III.SG.DEF } \\ \text { 'Jiñappu has felled the baobab tree.' (ss20140404_AmT) } & \end{array}$

With stative verbs, the suffix -e indicates emphasis or surprise, which is a property of completives (Bybee et al. 1994). This is exemplified in (64) below. 
(64)
Jiñappu na-sojet-e
Jiñappu(I.SG) REAL.I.3SG-be.stupid-CPL
'Jiñappu is (really) stupid!' (ss20140404_AmT)

4.3.4.2. The perfective aspect - reduplication. Verbal stem reduplication is a strategy used to express perfective meaning. With the perfective, the event may or may not be completed but is construed as a complete unit (Frawley 1992). This is exemplified in (65) and (66), which report bounded events with no real relevance to the current situation.

\begin{tabular}{|c|c|}
\hline Jiñappu & na-be-bet \\
\hline $\begin{array}{l}\text { Jiñappu(I.SG) } \\
\text { 'Jiñappu has }\end{array}$ & $\begin{array}{l}\text { REAL.I.3SG-fell-REDUP } \\
\text { the baobab tree.' (ss2014C }\end{array}$ \\
\hline Jiñappu & na-bba-bah \\
\hline Jiñappu(I.SG) & REAL.I.3SG-be.tall-be.tall \\
\hline
\end{tabular}

4.3.4.3. The venitive-completive -ulo. The venitive-completive -ulo, exemplified in (67), is a TAM suffix composed of the venitive -úl and the middle suffix $-o$. It indicates completion of a situation away from the here and now, but whose results are evident from the deictic centre.
Jiñappu
na-lo-ulo
Jiñappu(I.SG)
REAL.I.3SG-fall-VEN.CPL
'Jiñappu fell down where he was' (he is here now).

4.3.4.4. The habitual suffix $-e$. The habitual suffix $e$ - occurs only between the base and the reduplicant, as in (68). When habitual aspect is expressed by verbal morphology it is negated with the verbal suffix -érit (see (69)).

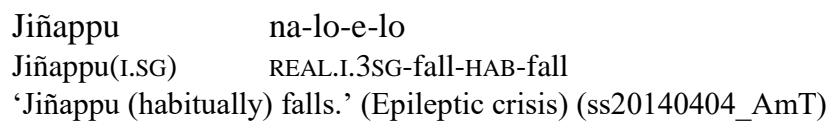

$\begin{array}{ll}\text { Jiñappu } & \text { a-lo-erit } \\ \text { Jiñappu(I.SG) } & \text { I.3sG-fall-HAB.NEG } \\ \text { 'Jiñappu does not (habitually) fall.' }\end{array}$

The habitual aspect can also be expressed analytically using the free morpheme nahi and its negative equivalent indi (see (70) and (71)).

$\begin{array}{llll}\text { nahi } & \text { gu-roddokk } & \text { ni } & \text { fuh } \\ \text { HAB } & \text { I.3PL-work.REDUP } & \text { PREP } & \text { [CLfu-[night(IV.SG) } \\ \text { 'They work at night.'(Part-obsv_2005) } & \end{array}$

$\begin{array}{llll}\text { indi } & \text { gu-rokk } & \text { ni } & \text { bu-jom } \\ \text { HAB.NEG } & \text { I.3PL-work } & \text { PREP } & \text { Cbbu-morning(III.SG) } \\ \text { 'They do not work in the morning.' } & & \end{array}$


4.3.4.5. The inactualis TAM suffix $-e n$. The inactualis suffix -en combines with both nouns and verbs, as pointed out in $\S 4.1 .3 .1$ above. With verbs, it expresses the meaning of past, and describes events or states which are no longer true, as in (73). In counterfactual conditional clauses, as in (73), it combines with the verbs in both the 'if clause' and the 'then clause', to refer to an event which failed to happen.
pay-om
na-ju-en-e
já-kkuj
father(I.SG)-1SG.POSS
REAL.I.3SG-be.able-INACT-CPL
CLja-wrestle
'My father was good at wrestling.' (ss20140404_AmT)
ú-pur-en-ut
me pan
u-jug-en-ol
2SG-go.out-INACT-NEG
NEG FUT
2sg-see-INACT-3sg.obj
'If you hadn't gone out you would have seen him/her' (ss20140404_AmT)

4.3.4.6. The anterior marker $b a-\ldots$-er. The prefix $b a$ - and the suffix -er (also realized in free variation as $m b a-\ldots-e r)^{20}$ jointly occur in the same verbal stems to express meanings which are cross-linguistically associated with the pluperfect (see (74)) or the future perfect (75). They signal past or future events which are relevant to another past or future event (see e.g., Bybee 1985).
ni-ttog-ol
o
ba-yog-er
REAL.1SG-find-3SG.OBJ
I.SG.PRO
CLba-be.tired-PERF

'(When I arrived) I found that he was already tired.'(Part-Obsv-2015)

$\begin{array}{llll}\text { pan } \quad \text { i-ttogol } & \text { o } & \text { ba-kkay-er } \\ \text { FUT } & \text { REAL.1sG-find-3sG.OBJ } & \text { I.SG.PRO } & \text { CLba-leave-PERF } \\ \text { 'I will find him already gone.' } & & \end{array}$

Though the prefix $\boldsymbol{b a}$ - and the suffix -er co-occur, I do not analyse them as TAM circumfixes, since the suffix -er can occur independently to describe anteriority comparable to the experiential perfect (Comrie 1976).

$\begin{array}{lllll}\text { nu-und-er-e } & \text { a-cce } & \text { gu-fog-e } & \text { ni } & \text { sí-ralam-ol? } \\ \text { REAL.2SG-hear-PERF-CPL } & \text { I.SG-other } & \text { I.3PL-bury-CPL } & \text { PREP } & \text { CLSu-money(II.PL)-3sG.POSS } \\ \text { 'Have you ever heard that someone has been buried with their money?' (ss20130620_JBB) }\end{array}$

4.3.4.7. Verbal negation. Verbal morphology is a common way to mark negation in African languages (Watters 2000; Childs 2003; Creissels et al. 2008). Three suffixes can mark negation in Eegimaa. The suffix -ut/-at negates declarative sentences describing properties, as in (77), or occurrences, as exemplified in (78).

\footnotetext{
${ }^{20}$ As can be seen in example (75) the suffix -er can appear without the prefix $b a$-in the expression of anteriority. Thus, it should be distinguished from the construction $b a-\ldots$-er discussed in 4.1.4.2, which functions as a circumfix only in the context of the derivation of manner nominalization, a context in which the elements $b a$ - and -er cannot be separated.
} 
(77) Appu a-bbag-ut

Appu I.3sG-be.tall-NEG

'Appu is not tall.'

(78) Appu a-tiñ-ut

Appu I.3sG-eat-NEG

'Appu has not eaten.'

The suffix -érit marks negation of habitual aspect, as exemplified in (79).

(79) Appu á-tiñ-erit

Appu I.3sG-eat-NEG.HAB

'Appu does not eat.'

Eegimaa also has (c) a negative suffix - erut, which may be glossed as 'not yet' and which expresses the idea that an event has not yet occurred, as in (80).

(80) Appu a-tiñ-erut

Appu I.3sG-eat-NOT.YET

'Appu has not eaten yet.'

4.3.4.8. The future. The future is formed with the particles pan and ban, which express 'general future' and 'immediate future' respectively (see (81) and (82)). Both general and immediate future expressions are negated using the particle mati (83).

$\begin{array}{llll}\text { pan } & \text { i-lob } & \text { ni } & \text { ja-om } \\ \text { FUT } & \text { 1SG-speak } & \text { PREP } & \text { mother(I.SG)-1SG.POSS }\end{array}$

'I will speak with my mother.'

$\begin{array}{llll}\text { ban } & \text { i-lob } & \text { ni } & \text { ja-om } \\ \text { IMM.FUT } & \text { 1 SG-speak } & \text { PREP } & \text { mother(I.SG)-1SG.POSS } \\ \text { 'I am going to speak with my mother.' } & & \\ & & & \\ \text { mati } & \text { i-lob } & \text { ni } & \text { ja-om } \\ \text { NEG.FUT } & \text { 1 SG-speak } & \text { PREP } & \text { mother(I.SG)-1SG.POSS } \\ \text { 'I will not/ I am not going to speak with my mother.' }\end{array}$

\section{Basic Syntax}

This section provides a discussion of the syntax of Eegimaa. I give an overview of NP structure and discuss verbal and non-verbal clauses. For a more detailed account of both simple and complex clauses in Eegimaa, see Bassène (2007) and Sagna (2008).

\subsection{Noun phrases}

5.1.1. General structure of the noun phrase. The basic structure of the NP in Eegimaa is presented in (84). A noun phrase consists minimally of a noun, with optional modifiers presented in brackets. 
Nominal modifiers include the indefinite determiner/pronoun $C L$ - $c c e$, which can be found in both pre-nominal (Pnl) and postnominal positions, showing agreement with the head of the NP, as exemplified in (85) and (86). There are minor semantic differences between the prenominal and postnominal uses of the determiner $C L$-cce, the clearest semantic distinction being that the latter tends to have an incremental meaning.

$\begin{array}{lll}\text { u-sen-om } & \text { bi-cce } & \text { bu-ra } \\ \text { 2SG-give-1SG.OBJ } & \text { III.SG-other } & \text { CLbu-bed(III.SG) } \\ \text { 'Give me another bed' (different from the first one) } & \end{array}$
u-sen-om
bu-ra
bi-cce
2SG-give-1SG.OBJ
CLbu-bed(III.SG)
III.SG-other
'Give me yet another bed' (different from and in addition to the first one)

All other NP modifiers such as definite articles, demonstratives, and adjectives occur in postnominal position. There is no indefinite article in Eegimaa. Eegimaa has a small category of around twenty non-derived adjectives, which occur in post-nominal position and must take a definite determiner in definite NPs, as in (87).
ga-rafa
gagu
ga-vugul gagu
ga-fum-o
me
CLga-bottle(V.SG) V.SG.DEF
V.SG-new V.SG.DEF V.SG.REL-break-MID SUBORD
'The new bottle that broke.'

5.1.2. Possessive phrases. Possessive phrases are formed either by the juxtaposition of two nouns, as in (88), in which case the possessor follows the possessum (the head), or by inserting the connective $C L$-ala between the possessor and the possessum (89), showing agreement with the head of the possessive phrase.
fu-how
bu-ra
CLfu-head(IV.SG)
CLbu-bed(III.SG)
lit.: 'a bed's head (top)'

$\begin{array}{lll}\text { ju-ppu } & \text { j-ala } & \text { fí-ttit } \\ \text { CLju-bird(VI.SG) } & \text { VI.SG-of } & \text { CLfu-mangrove(IV.SG) } \\ \text { lit.: 'a bird of the mangrove swamp' } & \end{array}$

5.2. Declarative clauses. Eegimaa has a fixed basic SVO constituent order. Subjects are obligatorily indexed on finite verbs with a subject marker which shows agreement in gender; number, and (third) person, with a controller noun which may or may not be present (see (90) and (91)). Transitive and intransitive clauses differ through the presence or absence of an object. Clausal negation is, as pointed out above, formed by adding the suffix - $u t$ to the verb to negate properties and the occurrences of events. 
$(90)$
Amisa
na-bba-bah
Amisa(I.SG)
REAL.I.3SG-be.tall-REDUP

'Amisa is tall.'

(91)
Amisa
a-mug-ut
e-jjamen
yayu
Amisa(I.SG)
I.3SG-kill-NEG
CLe-goat(II.SG)
II.SG.DEF

'Amisa has not killed the goat.'

5.2.2. Non-verbal predications. This survey of Eegimaa non-verbal predications draws on Dryer's (2007) typology of non-verbal predicates. Nouns and adjectives function as predicates in non-verbal clauses with or without copulas. Nominal predicates do not show agreement with their subjects, but copulas do agree with subjects whenever they occur. Copulas are optional, with adjectival and indefinite nominal predicates ('true nominal predicates' (Dryer 2007)), as exemplified in (92) and (93). Where copulas do occur, they follow the predicate (naam and foom below).
Amisa
é-gutum
(naam)
Amisa(I.SG)
CLe-hooded.vulture(II.SG)
(REAL.I.3SG.be)
'Amisa is a vulture.' (ss07_ufulunh-013)

$\begin{array}{llll}\text { fí-jjin } & \text { fafu } & \text { fu-vvugul } & \text { (foom) } \\ \text { CLfu-bull(IV.SG) } & \text { IV.SG.DEF } & \text { IV.SG.new } & \text { (IV.SG-be) } \\ \text { 'The bull is new.' (ss20150504_Yaag) } & & \end{array}$

With definite nominal predicates (true equational predicates in Dryer's (2007: 233) terms) it is possible to reverse the order between the subject and the predicate, and any semantic difference is likely to be one involving topic and focus, as in (94) and (95). Here, the copula is obligatory and it must occur between the subject and the predicate.

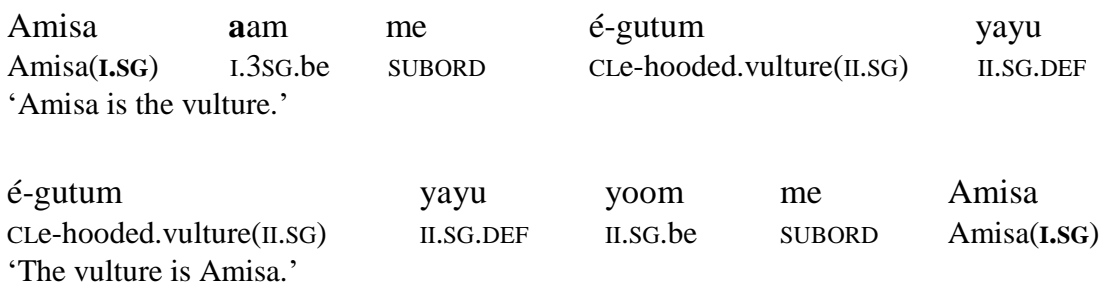

All non-verbal predicative constructions are negated by obligatorily using the negative copula let 'not be', which agrees with the subject of the clause, as in (96). Such negative copulas are common in African languages (Creissels et al. 2008).
Amisa
a-let
é-gutum
Amisa(I.SG)
I.3.SG-not.be
CLe-hooded.vulture(II.SG)
'Amisa is not a vulture.'

Locative clauses are formed by the obligatory use of the pronominal copula $u . C L . u$ 'be located at', followed by a place name or preposition plus a noun denoting a location. This is exemplified in (97). 
(97)

$\begin{array}{lll}\text { Honore } & \text { umu } & \text { tía } \\ \text { Honore(I.SG) } & \text { COP.I.SG.MED } & \text { outside } \\ \text { 'Honore is outside.' (Part-obsv_2015) } & \end{array}$

5.3. Imperatives and prohibitives. The imperative mood is formed by attaching a verbal prefix to the verbal stem, as in $u$-jow 'go!(2SG)' and ju-jow 'go!(2PL)'; it is negated using the prohibitive marker jambi, as illustrated in (98) and (99).

$$
\begin{array}{ll}
\text { jambi } & \text { u-jow } \\
\text { PROH } & \text { 2sG-go } \\
\text { 'Don't go! (sG)' }
\end{array}
$$

$$
\begin{array}{lr}
\text { Jambi } & \text { ju-jow } \\
\text { PROH } & \text { 2PL-go } \\
\text { 'Don't go! (PL)' }
\end{array}
$$

5.4. Negation outside verbal morphology. Negation outside the verbal word includes the use of the negative copula let (discussed in 5.1.1) which is also used to negate constituents as exemplified in (100). It also includes negative particles such as the prohibitive particle jambi (see Section 5.2), the habitual negative particle indi (see (101)), and the negative marker for futurity mati in (102).

$\begin{array}{llll}\text { (100) } & \begin{array}{l}\text { let-i } \\ \text { not.be-PASS } \\ \text { 'It is not one day.' }\end{array} & \begin{array}{l}\text { fu-nah } \\ \text { CLfu-day(IV.SG) }\end{array} & \begin{array}{l}\text { f-anur } \\ \text { IV.SG-one }\end{array} \\ \text { (101) } & \begin{array}{l}\text { indi } \\ \text { HAB.NEG }\end{array} & \begin{array}{l}\text { gu-lob } \\ \text { I.3PL-speak }\end{array} \\ & & \\ \text { 'They not do not speak.' } & \\ \text { (102) } & \text { mati } & \text { gu-lob } \\ & \begin{array}{l}\text { FUT.NEG } \\ \text { 'They will not speak.' }\end{array}\end{array}$

\section{Summary}

The phonology of Eegimaa is characterized by the typologically unusual occurrence of geminate consonants before vowels that are long in related Jóola languages. Other interesting phonological characteristics discussed here include [ATR] vowel harmony, the backness harmony of high vowels, lenition, nasal assimilation, and degemination. Most of the paper has, however, focused on the Eegimaa morphology. Among the most interesting phenomena surveyed in this section is the noun class system, analysed using the gender approach of Corbett (1991). A brief overview of the shape-based noun class semantics has also been provided. The other salient morphological phenomena examined here include affix ordering, but also, and the typologically uncommon expression of nominal TAM and alienability contrasts with the TAM suffix -en, and the overt classification of non-finite verbs using the same linguistic means as nouns, thus reflecting parallel semantic categorizations in the nominal and verbal domains. A discussion of the Eegimaa verbal 
extensions is also given, along with a diagram presenting the morphological structure of the verb. The brief overview of the syntax of Eegimaa focused on a discussion of different kinds of non-verbal predicative constructions and summaries of the NP structure and the simple clauses. Affix ordering and the semantics of the classification of non-finite verbs require further investigation.

\section{Abbreviations}

Roman numerals show Agreement classes/Genders (as defined in Corbett 1991). The sources of the examples are given on the free translation line. When no source is $t$ given, it means that as a native speaker I have provided the example myself.

$\begin{array}{llll}\text { ANTIC } & \text { Anticipative } & \text { NP } & \text { Noun phrase } \\ \text { ASSOC } & \text { Associative } & \text { OBJ } & \text { Object } \\ \text { ATR } & \text { Advanced Tongue Root } & \text { PASS } & \text { Passive } \\ \text { CAUS } & \text { Causative } & \text { PERF } & \text { Perfect } \\ \text { CL } & \text { Nominal morphological class } & \text { PL } & \text { Plural } \\ \text { COP } & \text { Copula } & \text { POSS } & \text { Possessive } \\ \text { CPL } & \text { Completive } & \text { PREP } & \text { Preposition } \\ \text { DEF } & \text { Definite (determiner) } & \text { PROH } & \text { Prohibitive } \\ \text { FUT } & \text { Future } & \text { REAL } & \text { Realis } \\ \text { HAB } & \text { Habitual } & \text { REC } & \text { Reciprocal } \\ \text { IMM } & \text { Immediate } & \text { REDUP } & \text { Reduplication } \\ \text { INACT } & \text { Inactualis } & \text { REFL } & \text { Reflexive } \\ \text { MED } & \text { Medial demonstrative } & \text { REL } & \text { Relative } \\ \text { MID } & \text { Middle voice } & \text { SG } & \text { Singular } \\ \text { N } & \text { Noun } & \text { SUBORD } & \text { Subordinate } \\ \text { NEG } & \text { Negation } & \text { VEN } & \text { Venitive }\end{array}$

\section{References}

Aikhenvald, Alexandra Y. 2000. Classifiers : A typology of noun categorization devices. Oxford: Oxford University Press.

Bassène, Alain-Christian. 2007. Morphosyntaxe du jóola banjal. Köln: Rüdiger Köppe Verlag. Bassene, Mamadou. 2012. Morphophonology of Joola Eegimaa. St. Paul, MN: The University of Minnesota dissertation.

Berndt, Wolfgang. 2003. Description de la phonologie du Diola-Bandial. Société Internationale de Linguistique, Dakar Sénégal.

Breedveld, J O. 1995. Form and meaning in Fulfulde: A morphological study of Maasinankoore. CNWS publications ; 32. Leiden: Research School CNWS.

Bybee, Joan L. 1985. Morphology: A study of the relation between meaning and form. Amsterdam/Philadelphia: John Benjamins. 
Bybee, Joan L., R Perkins \& W Pagliuca. 1994. The evolution of grammar: Tense, aspect, and modality in the languages of the world. Chicago and London: The University of Chicago Press.

Childs, G. Tucker. 2003. An introduction to African languages. Amsterdam: John Benjamins Publishing Company.

Clements, George N. 2000. Phonology. In Bernd Heine \& Derek Nurse (eds.), African languages. An introduction, 123-160. Cambridge: Cambridge University Press.

Cobbinah, Alexander \& Friederike Lüpke. 2014. When number meets classification: the linguistic expression of number in Baïnounk languages. In Anne Storch \& Gerrit J. Dimmendaal (eds.), Number - constructions and semantics: Case studies from Africa, Amazonia, India and Oceania, 199-220. Amsterdam/ Philadelphia: John Benjamins Publishing Company.

Cobbinah, Alexander Yao. 2013. Nominal classification and verbal nouns in Bä̈nounk Gubëeher. London, UK: The University of London dissertation.

Comrie, Bernard. 1976. Aspect. Cambridge: Cambridge Univeristy Press.

Contini-Morava, Ellen. 1997. Noun classification in Swahili: A cognitive-semantic analysis using a computer database. In R K Herbert (ed.), African languages at the crossroads: Papers from Kwaluseni, 599-628. Köln: Rüdiger Köppe.

Corbett, Greville G. 1991. Gender. Cambridge: Cambridge University Press.

Corbett, Greville G. 2000. Number. Cambridge: Cambeidge University Press.

Corbett, Greville G. 2006. Agreement. Cambridge: Cambridge University Press.

Corbett, Greville G. 2015. Hybrid nouns and their complexity. In Jürg Fleischer, Elisabeth Rieken \& Paul Widmer (eds.), Agreement from a diachronic perspective, 191-214. Berlin: De Gruyter Mouton.

Creissels, Denis. 1999. "Genres" indo-européens et "classes nominales" Niger-Congo. Faits de Langues 14. Paris: OPHRYS. 177-184.

Creissels, Denis. 2001. Les systèmes de classes nominales des langues Niger-Congo: prototype et variations. In Anna Sörés \& C Marchello-Nizia (eds.), Invariants et Variables dans les langues: Etudes typologiques (Linx, 45), 157-166. Nanterre: Université Paris X.

Creissels, Denis, Gerrit J. Dimmendaal, Zygmunt Frajzyngier \& Christa Ko. 2008. Africa as a morphosyntactic area. A linguistic geography of Africa, 86-150. Cambridge: Cabridge University Press.

Daniel, Michael \& Edith A. Moravcsik. 2013. The associative plural. In Matthew S. Dryer \& Martin Haspelmath (eds.), The World Atlas of Language Structures online. Leipzig: Max Planck Institute for Evolutionary Anthropology: Available online at http://wals.info/chapter/36, Accessed on 2015-08-29.

Di Garbo, Francesca. 2014. Gender and its interaction with number and evaluative morphology: An intra- and intergenealogical survey of Africa. Stockholm, Sweden: The University of Stockholm dissertation.

Dryer, Matthew S. 2007. Clause types. In Timothy Shopen (ed.), Language typology and syntactic description, vol. 1, 224-275. Cambridge: Cambridge University Press.

Frawley, William. 1992. Linguistic semantics. Hillsdale, New Jersey: Lawrence Erlbaum Associates.

Greenberg, Joseph H. 1978. How do languages acquire gender markers? In Joseph H Greenberg, Charles A Ferguson \& A Moravcsik Edith (eds.), Universals of human language, vol. 3, 4782. Stanford: Stanford University Press.

Grinevald, Colette. 2000. A morphosyntactic typology of classifiers. In Gunter Senft (ed.), Systems of nominal classification, 50-92. Cambridge: Cambridge University Press.

Hantgan-Sonko, Abbie. 2017. A weight-based analysis of Jóola Eegimaa lenition. In Samuel G. Obeng \& Christopher R. Green (eds.), African linguistics in the 21st Century: Essays in 
honor of Paul Newman, 47-56. Köln: Rüdiger Köppe.

Hantgan, Abbie, Serge Sagna \& Stuart Davis. 2016. Mora preservation in Gújjolaay Eegimaa reduplication. Paper presented at the 24th Manchester Phonology Meeting (MFM),The University of Manchester, Manchester, 26-28 May 2016.

Haspelmath, Martin. (To appear). Explaining alienability contrasts in adpossessive constructions: Predictability vs. iconicity. Zeitschrift für Sprachwissenschaft.

Haspelmath, Martin. 1989. From purposive to infinitive - a universal path of grammaticalization. Folia Linguistica Historica 10. 287-310.

Hopper, Paul J. \& Sandra A Thompson. 1980. Transitivity in grammar and discourse. Language 56: 2. 251-299.

Kennedy, M. A. 1964. Dialect in Diola. JAL 3. 96-101.

Koptjevskaja-Tamm, Maria. 1993. Nominalizations. London, New York: Routledge.

Kopytoff, Igor. 1987. The internal African frontier: the making of African political culture. In Igor Kopytoff (ed.), The African frontier: The reproduction of traditional African societies, 3-84. Bloomington, and Indianapolis: Indiana University Press.

McGregor, William B. 2002. Verb classification in Australian languages. Berlin : New York: Walter de Gruyter.

Mufwene, Salikoko S. 1980. Bantu class prefixes: inflection or derivation? Chicago Linguistic Society 16. 246-258.

Næss, Åshild. 2007. Prototypical Transitivity. Amsterdam/Philadelphia: John Benjamins.

Newman, Paul. 1990. Nominal and verbal plurality in Chadic. Dordrecht, Holland: Foris Publications.

Noonan, Michael. 2007. Complementation. In Shopen Timothy (ed.), Language typology and syntactic description, vol. 2, 52-150. Cambridge: Cambridge University Press.

Nordlinger, Rachel \& Louisa Sadler. 2004. Nominal tense in crosslinguistic perspective. Language 80(4). 776-806.

Pozdniakov, Konstantin. 2010. La classification nominale : A la croisée des paradigmes. In Franck Floricic (ed.), Essais de typologie et de linguistique générale: mélanges offerts à Denis Creissels, 87-105. ENS Éditions.

Pozdniakov, Konstantin \& Guillaume. (In press) Segerer. A Genealogical classification of Atlantic languages. Oxford guide to the world's languages: Atlantic. Oxford: Oxford University Press.

Safir, Ken \& Mamadou Bassene. 2014. Verb stems in Eegimaa: How compositional is agglutinative morphology? Deparmental Seminar, SOAS, London. 19 March 2014.

Sagna, Serge. 2008. Formal and semantic properties of the Gújjolaay Eegimaa (A.k.a Banjal) nominal classification system. London, UK: The University of London dissertation.

Sagna, Serge. 2010. Issues in noun classification and noun class assignment in Gújjolaay Eegimaa (Banjal) and other Jóola languages. Studies in African Linguistics 39(1). 1-33.

Sagna, Serge. 2011a. Semantic categorisations in the Gújjolaay Eegimaa collectives and distributives. In Peter K. Austin, Oliver Richards-Bond, David Nathan \& Lutz Marten (eds.), Proceedings of Conference on Language Documentation and Linguistic Theory 3, 1-10. London: Department of Linguistics, SOAS.

Sagna, Serge. 2011b. L'alphabet du Gújjolaay Eegimaa. http://www.humanities.manchester.ac.uk/medialibrary/llc/files/sagna/R\%E9sum\%E9Alphabet-Eegimaa-Serge.pdf (15 Nov. 2016). http://www.humanities.manchester.ac.uk/medialibrary/llc/files/sagna/R\%E9sum\%E9Alphabet-Eegimaa-Sagna Serge.pdf (25 August, 2015).

Sagna, Serge. 2012. Physical properties and culture-specific factors as principles of semantic categorisation in the Gújjolaay Eegimaa noun class system. Cognitive Linguistics 23 (1). 129-163.

Sagna, Serge. 2013. Aspects of the categorization of nonfinite verbs in Gújjolaay Eegimaa. Paper presented at the Linguistic Association of Great Btritain (LAGB): SOAS, University of 
London, 28-31 August 2013.

Sagna, Serge. 2017. Morphological alternation and event delimitation in Eegimaa. Italian Journal of Linguistics 291. 53-74.

Sambou, Pierre. 2007. Morphosyntaxe du joola Karon. Thèse de Doctorat. Département de Linguistique, Université Cheikh Anta Diop.

Sambou, Pierre Marie. 1979. Diola Kaasa Esuulaalur: Phonologie, Morphophonologie et Morphologie. Thèse de Doctorat. Département de Linguistique, Université Cheikh Anta Diop.

Sambou, Pierre Marie. 1989. Approche Phonologique du Joola Eegimaa. Annales de la Faculté des Lettres et Sciences Humaines 19. Dakar: Nouvelles Editions Africaines. 191-205.

Sambou, Pierre Marie \& Jeanne Lopis. 1981. Le trait ATR et ses manifestations en joola et en noon. Bulletin de l'Institut Fondamental d'Afrique Noire 43. Dakar: IFAN.

Sapir, David J. 1965. A grammar of Diola-Fogny: A language spoken in the Basse-Casamance region of Senegal. Cambridge: Cambridge University Press.

Sapir, David J. 1971. West Atlantic: An Inventory of the languages, their Noun Class systems and consonant Alternations. In Thomas Seboek A. (ed.), Current Trends in Linguistics, vol. 7, 45-112. The Hague: Mouton.

Schadeberg, Thilo. 2001. Number in Swahili grammar. Afrikanistische Arbeitspapiere 68(Swahili forum VIII). 7-16.

Schultze-Berndt, Eva \& Serge Sagna. 2010. Towards a typology of overt verb classification. Paper presented at the Categorizing human experience: classification in languages and knowledge systems (COST Action 31, Stability and Adaptation of Classification Systems in a Cross-cultural Perspective) Final Conference. EHESS, Paris, 15-16 May 2010.

Spencer, Andrew. 2013. Lexical relatedness: A paradigm based model. Oxford: Oxford University Press.

Tendeng, Odile. 2007. Le Gusiilay: Un essai de systématisation. Une contribution à l'étude du Jóola. Berlin: Peter Lang.

Watson, Rachel. 2015. Kujireray: morphosyntax, noun classification and verbal nouns. London, UK: The University of London dissertation.

Watters, Jonh R. 2000. Syntax. In Bernd Heine \& Derek Nurse (eds.), African languages: an introduction, 194-230. Cambridge: Cambridge University Press.

Welmers, William E. 1973. African language structure. Berkeley, Los Angeles, and London: University of California Press.

Serge Sagna <eakkut@gmail.com>

University of York,

United Kingdom 